\title{
ABIETATRIENES DITERPENOIDS FROM Sagittaria montevidensis SSP Montevidensis
}

\author{
Clara M. A. Tanaka ${ }^{\dagger}$ Vanessa S. C. O. Radke e Cleuza C. da Silva \\ Departamento de Química, Universidade Estadual de Maringá, Av. Colombo, 5790, 87020-900 Maringá - PR, Brasil \\ Celso V. Nakamura \\ Departamento de Análises Clínicas, Universidade Estadual de Maringá, Av. Colombo, 5790, 87020-900 Maringá - PR, Brasil \\ Pollyanna L. de Oliveira, Lucilia Kato e Cecília M. A. de Oliveira* \\ Instituto de Química, Universidade Federal de Goiás, Campus II, 74000-970 Goiânia - GO, Brasil
}

Recebido em 1/10/08; aceito em 14/7/09; publicado na web em 25/11/09

\begin{abstract}
The antimicrobial properties of the hexane, hexane/EtOAc and methanol fractions of the fresh petioles of Sagittaria montevidensis ssp montevidensis (Alismataceae) were evaluated against fungi and Gram-negative and Gram-positive bacteria. A new abietatriene-

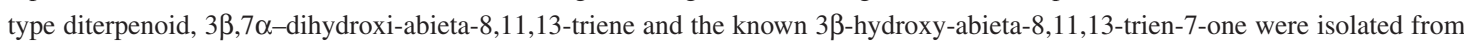
the most active fraction tested and the structures of these compounds were elucidated by data including IR, EIMS, and 1D and 2D NMR spectra.
\end{abstract}

Keywords: Sagittaria; abietatrienes; antimicrobial activity.

\section{INTRODUCTION}

The genus Sagittaria (Alismataceae) comprises 25 species of herbaceous aquatic plants that are distributed throughout the Americas in tropical regions. No evidence has been found for the use of Sagittaria montevidensis ssp montevidensis in traditional medicine. However, others Sagittaria species are known to produce antibacterial compounds such as clerodane, pimarane, labdane and rosane-type diterpenoids. ${ }^{1,2}$ During of our survey of the active substances from Alistamaceae species, ${ }^{3-6}$ fractions of different polarity deriving from the crude methanolic extract of $S$. montevidensis ssp montevidensis were tested against a representative set of fungi and bacteria strains. Chromatographic treatment of the most active fraction led to the isolation of a new diterpenoid abietatriene derivative, $3 \beta, 7 \alpha-$ dihydroxi-abieta-8,11,13-triene (1), along with a known diterpenoid, $3 \beta$-hydroxy-abieta-8,11,13-trien-7-one (2). The structures of the compounds were determined by spectroscopic analysis including EIMS, IR, and $1 \mathrm{D}$ and $2 \mathrm{D}{ }^{1} \mathrm{H},{ }^{13} \mathrm{C} \mathrm{NMR}$ data and also by comparison of its NMR data with those of related compounds.

\section{EXPERIMENTAL}

\section{General experimental procedures}

1D and 2D ${ }^{1} \mathrm{H},{ }^{13} \mathrm{C}$ NMR spectra were acquired on a Varian Mercury plus BB spectrometer, operating at $300.059 \mathrm{MHz}\left({ }^{1} \mathrm{H}\right)$ and $75.458 \mathrm{MHz}\left({ }^{13} \mathrm{C}\right)$ for a $\mathrm{CDCl}_{3}$ solution using TMS as an internal standard. Mass spectrometry was performed on a Shimadzu GC-MS QP 2000A, 70 eV.

\section{Plant material}

The plant material was collected in Curitiba, Paraná, Brazil and authenticated by Dr. M. do C. Amaral (IB-UNICAMP). A voucher specimen (\# UEC 115194) was deposited in the Herbarium of the Instituto de Biologia, Universidade Estadual de Campinas, Campinas-SP.

\footnotetext{
† This paper is dedicated to our colleague and friend Clara M. A. Tanaka in memoriam

*e-mail: cecilia@quimica.ufg.br
}

\section{Extraction and isolation}

Fresh petioles $(86.0 \mathrm{~g})$ of $S$. montevidensis ssp montevidensis were extracted with $\mathrm{MeOH}$. After removal of the solvent by vacuum, the residue $(32.0 \mathrm{~g})$ was partitioned between EtOAc and $\mathrm{H}_{2} \mathrm{O}$. The EtOAc $(6.0$ g) extract was subjected to column chromatography on a silica gel 60 to give $n$-hexane, $n$-hexane/EtOAc (95:5, 90:10, 80:20, 70:30, 60:40, 50:50) and $\mathrm{MeOH}$ fractions. These subfractions were named subfractions $\mathrm{A}, \mathrm{B}$, C, D, E, F, G and H, respectively. The fraction E eluted with $n$-hexane/ EtOAc 70:30 (602.0 mg) was further purified by column chromatography (CC) on silica gel 60 using an $n$-hexane-EtOAc gradient solvent system to obtain compounds $\mathbf{1}(12.0 \mathrm{mg}$ ) and $\mathbf{2}(40.0 \mathrm{mg})$.

\section{$3 \beta$-hydroxy-abieta-8,11,13-trien-7-one $(2)^{7,8}$}

Yellowish oil: $\mathrm{RMN}-{ }^{1} \mathrm{H} \delta\left(300 \mathrm{MHz}, \mathrm{CDCl}_{3}\right): 7.80(\mathrm{~d}, 2.1 \mathrm{~Hz}, \mathrm{H}-14)$, 7.40 (dd, 8.2; $2.1 \mathrm{~Hz}, \mathrm{H}-12$ ), 7.28 (d, 8.2 Hz, H-11), 3.36 (dd, 4.8, 10.8 Hz, H-3), 2.90 (sept, 6.0 Hz, H-15), 2.73 (d, 11.4 Hz, H-6ß), 2.72 (d, $6.6 \mathrm{~Hz}, \mathrm{H}-6 \alpha$ ), 2.40 (m, H-1), 1.86 (dd, 11.4 and 6.6, H-5), 1.82-1.90 (m, H-2), 1.24 (d, 6.0 Hz, H-16), 1.24 (d, $6.0 \mathrm{~Hz}, \mathrm{H}-17), 1.24$ (s, H-20), 1.05 (s, H-19), 0.97 (s, H-18). NMR ${ }^{13} \mathrm{C}\left(75 \mathrm{MHz} ; \mathrm{CDCl}_{3}\right)$ : 199.7 (C-7), 153.0 (C-9), 147.0 (C-13), 132.7 (C-12), 130.5 (C-8), 125.0 (C-14), 123.9 (C-11), 78.0 (C-3), 48.4 (C-5), 38.7 (C-4), 37.4 (C-10), 36.1 (C-1), 35.7 (C-6), 33.5 (C-15), 27.4 (C-2), 27.3 (C-19), 23.7 (C-20), 23.6 (C-17), 23.2 (C-16), 14.8 (C-18).

\section{Microorganisms used and growth condition}

The fractions above were assayed against Gram-positive and Gramnegative bacteria by a broth microdilution assay to determine the minimal inhibitory concentrations (MICs) as described below. The assays were performed with Escherichia coli ATCC 25922, Pseudomonas aeruginosa ATCC 15442, Bacillus subtilis ATCC 6623, and Staphylococcus aureus ATCC 25923 obtained from the American Type Culture Collection (ATCC, Rockville, MD). For the antifungal assay, a single clinical isolate of each species (Candida albicans, C. krusei, C. parapsilosis, and C. tropicalis), obtained from vaginal mucosa, was selected for testing. The bacteria were maintained in Tryptic Soy Agar (Difco). The yeast was maintained in Sabouraud Dextrose Agar (Difco).

\section{Antifungal susceptibility testing}

The MICs of all the fractions and reference antifungal compounds 
were determined by microdilution techniques in RPMI 1640 (Sigma Chemical Co., St. Louis, MO) for yeast. ${ }^{9}$ Inoculates were prepared in the same medium at a density adjusted to a $0.5 \mathrm{McFarland}$ turbidity standard $\left(10^{6}\right.$ colony-forming units $\left.[\mathrm{CFU}] \mathrm{m} / \mathrm{L}\right)$ and diluted to a $1: 10$ ratio for the broth microdilution procedure. Microtiter trays were incubated at $37^{\circ} \mathrm{C}$, and the MICs were recorded after $24 \mathrm{~h}$ of incubation. Two susceptibility endpoints were recorded for each isolate. The MIC was defined as the lowest concentration of compounds at which the tested microorganism does not demonstrate visible growth. Nystatin (Sigma Chemical Co., St. Louis, MO, USA) was included in the test as a control. When the MIC was equal or smaller than $100 \mu \mathrm{g} / \mathrm{mL}$, the antimicrobial activity was considered significant. If the fractions displayed a MIC from 100 to $500 \mu \mathrm{g} / \mathrm{mL}$, the antimicrobial activity was considered moderate; from 500 to $1000 \mu \mathrm{g} / \mathrm{mL}$, the antimicrobial activity was considered weak; over $1000 \mu \mathrm{g} / \mathrm{mL}$, the fractions were considered inactive. ${ }^{10}$

\section{Antibacterial susceptibility testing}

The MICs of all the extracts and reference antibiotics (tetracycline, vancomycin, and penicillin - Sigma Chemical Co., St. Louis, MO, US) were determined by microdilution techniques in Mueller-Hinton broth (Difco) according to CLSI. ${ }^{9}$ Inoculates were prepared in the same medium at a density adjusted to a $0.5 \mathrm{McFarland}$ turbidity standard $\left(10^{8}\right.$ colony-forming units $\left.\left.[\mathrm{CFU}]\right) / \mathrm{mL}\right]$ and diluted $1: 10$ for the broth microdilution procedure. Microliter plates were incubated at $37^{\circ} \mathrm{C}$ and the MICs were recorded after $24 \mathrm{~h}$ of incubation. Two susceptibility endpoints were recorded for each isolate. The MIC was defined as the lowest concentration of compounds at which the tested microorganism did not demonstrate visible growth.

\section{RESULT AND DISCUSSION}

The results of the preliminary screening for antimicrobial activity of all fractions are summarized in Table 1, which shows that six among ten fractions demonstrated significant activity against at least one of the microorganisms tested. However, the most active fraction was hexane/ EtOAc (70:30, fraction E) with an $\mathrm{MIC}=31.2 \mu \mathrm{g} / \mathrm{mL}$ against $C$. krusei. Therefore, it was purified by sequential chromatographic techniques, with the metabolites $\mathbf{1}$ and $\mathbf{2}$ (Figure 1) as the major constituents. Compound $\mathbf{2}$ was identified as 3 $\beta$-hydroxy-abieta-8,11,13-trien-7-oneby comparison of the IR, ${ }^{1} \mathrm{H}$ NMR, and ${ }^{13} \mathrm{C}$ NMR spectra with those already published. We now report the characterization of $\mathbf{1}$.

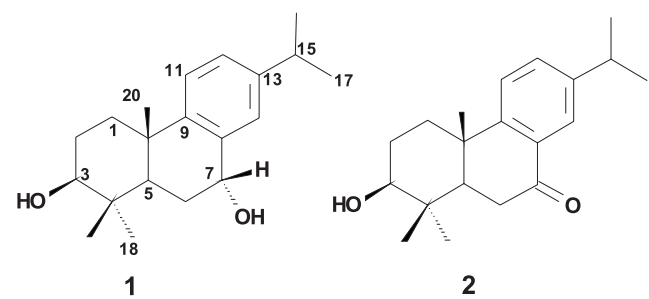

Figure 1. Structure of abietatrienes 1 and 2

Compound $1[\alpha]_{\mathrm{D}}=+17(\mathrm{MeOH}, c .0 .011)$, was isolated as a yellowish oil. HRMS suggested a molecular formula of $\mathrm{C}_{20} \mathrm{H}_{30} \mathrm{O}_{2}$, $\mathrm{m} / \mathrm{z}, 302.2232$ (calculated $\mathrm{m} / \mathrm{z}, 302.2238$ ). The IR spectrum showed absorption bands at $v_{\max } 3400$ and $1600 \mathrm{~cm}^{-1}$, which could be attributed to hydroxyl groups and double bonds, respectively. The ${ }^{1} \mathrm{H}$ NMR (Table 2) spectrum showed signals for a trisubstituted aromatic ring at $\delta_{\mathrm{H}} 7.19(1 \mathrm{H}, \mathrm{d}, J=1.8 \mathrm{~Hz}), 7.18(1 \mathrm{H}, \mathrm{d}, J=8.2 \mathrm{~Hz})$ and $7.12(1 \mathrm{H}$, $\mathrm{dd}, J=8.2$ and $1.8 \mathrm{~Hz})$, oxymethine at $4.85(1 \mathrm{H}, \mathrm{t}, J=3.0 \mathrm{~Hz})$ and 3.35 $(1 \mathrm{H}, \mathrm{dd}, J=10.8$ and $5.4 \mathrm{~Hz})$, methylenes at $2.30(1 \mathrm{H}, \mathrm{m}), 2.00(2 \mathrm{H}$, ddd, $J=9.0, J=5.7$ and $3.0 \mathrm{~Hz}), 1.70-1.80(2 \mathrm{H}, \mathrm{m})$ and $1.56(1 \mathrm{H}, \mathrm{dd}$, $J=13.2$ and $5.4 \mathrm{~Hz})$, a septet at $2.87(1 \mathrm{H}, J=6.9 \mathrm{~Hz})$ and methyl groups at $1.23(6 \mathrm{H}, \mathrm{d}, J=6.9 \mathrm{~Hz}), 1.13(3 \mathrm{H}, \mathrm{s}), 1.09(3 \mathrm{H}, \mathrm{s})$ and $0.90(3 \mathrm{H}, \mathrm{s})$. From the ${ }^{13} \mathrm{C}$ NMR (Table 2) and DEPT 20 carbons were detected and assigned by HMQC to a aromatic ring $\left(\delta_{\mathrm{C}} 146.9,146.8,136.1\right.$, $127.9,126.9$ and 124.7$)$, two oxygenated methine $\left(\delta_{C} 78.9\right.$ and 68.7$)$, three methylene groups $\left(\delta_{\mathrm{C}} 36.8,28.5\right.$ and 28.2$)$, two methines $\left(\delta_{\mathrm{C}}\right.$ 43.8 and 33.7 ), two $\operatorname{sp}^{3}$ quaternary carbons (38.7 and 37.8) and finally four methyl signals at 28.1, 24.2, $24.1(2 \mathrm{x})$ and 15.7. Comparison of above data and those of $3 \beta$-hydroxy-abieta-8,11,13-trien-7-one $2,7,8$ showed a good agreement except for the presence of an additional oxymethine group in the compound $\mathbf{1}$ replacing the carbonyl group observed in 2. Analysis of the ${ }^{1} \mathrm{H}-{ }^{1} \mathrm{H}$ COSY experiment (Figure 2) showed correlations between the oxymethine at $\delta_{\mathrm{H}} 4.85\left(\delta_{\mathrm{C}} 68.7\right)$ and protons $\mathrm{H}-5, \mathrm{H}-6$ indicating that the extra hydroxyl group was possibly situated on C-7. This assumption was further confirmed by an HMBC experiment, where correlation of $\mathrm{H}-5$ with the C-7 was observed. Additional HMBC correlations of C-3/H-18, H-19, H-1 $\beta$ and $\mathrm{C}-12 / \mathrm{H}-14, \mathrm{H}-11$ and a NOESY experiment, showing that the axial methyl protons at $\mathrm{C}-19$ gave cross peaks with the 20-methyl protons and the $\mathrm{H}-2 \beta$, confirmed the structural similarities of $\mathbf{1}$ and 2. The presence and location of the isopropyl group linked to quaternary aromatic carbon was supported by chemical shift and NOESY

Table 1. Minimum inhibitory concentrations MICs $(\mu \mathrm{g} / \mathrm{mL})$ of the fractions of S. montevidensis spp montevidensis

\begin{tabular}{|c|c|c|c|c|c|c|c|c|c|}
\hline & A & $\mathrm{B}$ & $\mathrm{C}$ & $\mathrm{D}$ & $\mathrm{E}$ & $\mathrm{F}$ & G & $\mathrm{H}$ & References \\
\hline \multicolumn{10}{|l|}{ Gram-positive bacteria } \\
\hline $\begin{array}{l}\text { Staphylococcus aureus ATCC } \\
25923\end{array}$ & 1000 & 125 & 1000 & 125 & 62.5 & 125 & 250 & $>1000$ & $0.00975^{\mathrm{a}}$ \\
\hline Bacillus subtilis ATCC 6623 & $>1000$ & $>1000$ & 250 & 250 & 125 & 125 & 125 & $>1000$ & $0.09^{\mathrm{b}}$ \\
\hline \multicolumn{10}{|l|}{ Gram-negative bacteria } \\
\hline Escherichia coli ATCC 25922 & $>1000$ & $>1000$ & $>1000$ & $>1000$ & 1000 & 1000 & $>1000$ & $>1000$ & $0.78^{\mathrm{c}}$ \\
\hline $\begin{array}{l}\text { Pseudomonas aeruginosa ATCC } \\
15442\end{array}$ & $>1000$ & $>1000$ & $>1000$ & $>1000$ & $>1000$ & $>1000$ & $>1000$ & $>1000$ & $3.125^{\mathrm{c}}$ \\
\hline \multicolumn{10}{|l|}{ Fungi } \\
\hline Candida albicans & $>1000$ & $>1000$ & $>1000$ & 500 & 500 & 250 & 500 & 1000 & $1.0^{\mathrm{d}}$ \\
\hline Candida parapsilosis & 500 & 500 & 500 & 500 & 125 & 250 & 250 & 500 & $8.0^{\mathrm{d}}$ \\
\hline Candida tropicalis & $>1000$ & 500 & 1000 & 250 & 125 & 250 & 250 & $>1000$ & $8.0^{\mathrm{d}}$ \\
\hline Candida krusei & 500 & 62.5 & 250 & 62.5 & 31.2 & 62.5 & 62.5 & 500 & $4.0^{\mathrm{d}}$ \\
\hline
\end{tabular}

a Penicillin; ${ }^{b}$ Vancomycin; ${ }^{\mathrm{c}}$ Tetracycline; ${ }^{\mathrm{d} N y s t a t i n}$ data from experiments in triplicate, MIC defined as the lowest concentration for which no growth was observed in every tested well. Subfractions A-H were referred to as hexane, hexane/EtOAc 95:5, 90:10, 80:20, 70:30, 60:40, 50:50 mixtures and methanol subfractions, respectively. 
Table 2. ${ }^{1} \mathrm{H},{ }^{13} \mathrm{C}$ NMR data of the compound $\mathbf{1}\left(\mathrm{CDCl}_{3}\right)$, COSY and HMBC correlations

\begin{tabular}{|c|c|c|c|c|}
\hline & ${ }^{13} \mathrm{C}$ & ${ }^{1} \mathrm{H}$ & COSY & HMBC \\
\hline 1 & 36.8 & $1 \beta: 2.30(\mathrm{dt}, J=13.2$ and 3.0$) ; 1 \alpha: 1.56(\mathrm{ldd}, J=5.4$ and $13.2 \mathrm{~Hz})$ & & $\mathrm{H}-20$ \\
\hline 2 & 28.2 & $1.70-1.80(\mathrm{~m})$ & $\mathrm{H}-1 \beta$ & $\mathrm{H}-1 \beta$ \\
\hline 3 & 78.9 & $3.35(\mathrm{dd}, J=10.8$ and $5.4 \mathrm{~Hz})$ & $\mathrm{H}-2$ & $\mathrm{H}-18 ; \mathrm{H}-19$ and $\mathrm{H}-1 \beta$ \\
\hline 4 & 38.7 & - & & $\mathrm{H}-18$ and $\mathrm{H}-19$ \\
\hline 5 & 43.8 & $1.65(\mathrm{dd}, J=9.0$ and $5.7 \mathrm{~Hz})$ & H-6 & H-20 \\
\hline 6 & 28.5 & $2.00(\mathrm{ddd}, J=9.0,5.7$ and $3.0 \mathrm{~Hz})$ & $\mathrm{H}-5$ & \\
\hline 7 & 68.7 & $4.85(\mathrm{bt}, J=3.0 \mathrm{~Hz})$ & H-6 & $\mathrm{H}-5$ \\
\hline 8 & 136.1 & - & & \\
\hline 9 & 146.8 & - & & H-20 \\
\hline 10 & 37.8 & - & & H-20 \\
\hline 11 & 124.7 & $7.18(1 \mathrm{H}, \mathrm{d}, J=8.2 \mathrm{~Hz})$ & & \\
\hline 12 & 126.9 & $7.12(1 \mathrm{H}, \mathrm{dd}, J=8.2$ and $1.8 \mathrm{~Hz})$ & & $\mathrm{H}-11$ and $\mathrm{H}-14$ \\
\hline 13 & 146.9 & - & & \\
\hline 14 & 127.9 & $7.19(1 \mathrm{H}, \mathrm{d}, J=1.8 \mathrm{~Hz})$ & & \\
\hline 15 & 33.7 & $2.87(1 \mathrm{H}, \mathrm{sep}, J=6.9 \mathrm{~Hz})$ & $\mathrm{H}-16$ and $\mathrm{H}-17$ & $\mathrm{H}-16$ and $\mathrm{H}-17$ \\
\hline 16 & $24.1^{a}$ & $1.23(3 \mathrm{H}, \mathrm{d}, J=6.9 \mathrm{~Hz})$ & & \\
\hline 17 & $24.2^{a}$ & $1.23(3 \mathrm{H}, \mathrm{d}, J=6.9 \mathrm{~Hz})$ & & \\
\hline 18 & 15.7 & $0.90(3 \mathrm{H}, \mathrm{s})$ & & H-19 \\
\hline 19 & 28.1 & $1.09(3 \mathrm{H}, \mathrm{s})$ & & H-18 \\
\hline 20 & 24.1 & $1.13(3 \mathrm{H}, \mathrm{s})$ & & \\
\hline
\end{tabular}

${ }^{a}$ interchangeable signals

correlations of $\mathrm{H}-16$ (H-17) with $\mathrm{H}-14$. This assumption was further confirmed by a NOE experiment, where correlation of $\mathrm{H}-14$ with the $\mathrm{H}-7$ was observed.

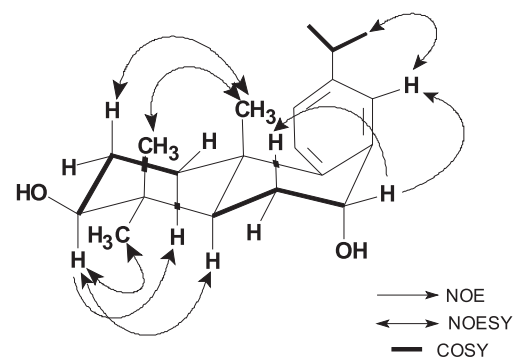

Figure 2. COSY, NOESY and NOE correlations observed for compound $\mathbf{1}$

The NOESY and NOE experiments as well as coupling constants established the relative configuration of the compound 1. Proton $\mathrm{H}-3$ $\left(J_{3 \mathrm{ax}, 2 \mathrm{eq}}=5.4\right.$ and $\left.J_{3 \mathrm{ax}, 2 \mathrm{ax}}=10.8 \mathrm{~Hz}\right)$ had an $\alpha$-disposition as showed by its coupling constants. It was further supported by NOESY correlations of H-3 with H-5 and H-3 with Me-19. No NOESY correlation was observed between $\mathrm{H}-7$ and $\mathrm{H}-5$ or $\mathrm{H}-7$ and $\mathrm{H}-19$, but the coupling constant corresponding to $\mathrm{H}-7$ (bt, $J=3.0 \mathrm{~Hz}$ ) and the ${ }^{13} \mathrm{C}$ NMR chemical shift values $^{11}$ suggests an $\alpha$-disposition of the hydroxyl group at the C-7. These configurations (Figure 2) were supported by an NOE spectrum that exhibited effects between $\mathrm{H}-3(\delta 3.35)$ with $\mathrm{H}-5(\delta 1.65)$ and $\mathrm{H}-1 \alpha$ $(\delta 1.56)$; H-7 ( $\delta 4.85)$ with H-6 $\beta(\delta 2.00)$ and H-14 ( $\delta 7.19)$. Therefore, compound 1 was assigned to be $3 \beta, 7 \alpha$-hydroxi-abieta-8,11,13-triene.

Finally, a literature survey revealed that abietane-type diterpenoids are recognized to inhibit Gram-positive bacteria and some fungi species with appreciable MIC values. ${ }^{12}$ Therefore, compounds $\mathbf{1}$ and $\mathbf{2}$ may merit further experiments to evaluated their antimicrobial activities.

\section{SUPPLEMENTARY MATERIAL}

Available at http://quimicanova.sbq.org.br, in format .PDF, with access free.

\section{ACKNOWLEDGEMENTS}

The authors wish to thank the Conselho Nacional de Desenvolvimento Científico e Tecnológico (CNPq) for their financial support and for Coordenação de Aperfeiçoamento de Pessoal de Ensino Superior (Capes) for the fellowship provided to P. L. de Oliveira.

\section{REFERENCES}

1. Liu, X.-T.; Pan Q.; Shi, Y.; Williams, I. D.; Sung, H. H.-Y.; Zhang, Q.; Liang, J.-Y.; Ip, N. Y.; Min, Z. D.; J. Nat. Prod. 2006, 69, 255.

2. Liu, X.-T.; Shi, Y.; Yu, B.; Williams, I. D.; Sung, H. H.-Y.; Zhang, Q.; Liang, J.-Y.; Ip, N. Y.; Min, Z. D.; Planta Medica 2007, 73, 84.

3. Tanaka, C. M. A.; Sarragiotto, M. H.; Spector, J. Z.; Marsaioli, A. J.; Phytochemistry 1997, 44, 1547.

4. Costa, M.; Tanaka, C. M. A.; Imamura, P. M.; Marsaioli, A. J.; Phytochemistry 1999, 50, 117.

5. Radke, V. S. C. O.; Tanaka, C. M. A.; Biochem. Syst. Ecol. 2004, 32, 529.

6. Radke, V. S. C. O.; Amaral, M. C. E.; Schuquel, I. T. A.; da Silva, C. C.; de Oliveira, C. M. A.; Tanaka, C. M. A.; J. Braz. Chem. Soc. 2007, 18, 444.

7. Burnell, R. H.; Coté, C.; Théberge, N.; J. Nat. Prod. 1993, 9, 1459.

8. Seca, A. M. L.; Silva, A. M. S.; Bazzocchi, I. L.; Jimenez, I. A.; Phytochemistry 2008, 69, 498.

9. CLSI - Clinical and Laboratory Standards Institute; Approved standard M7-A6; Methods for dilution antimicrobial susceptibility tests for bacteria that grow aerobically, Pennsylvania, US., 2005a.

10. Rios, J. L.; Recio, M. C.; J. Ethnopharmacol. 2005, 100, 80.

11. Del Corral, J. M. M.; Gordaliza, M.; Salinero, M. A.; San Feliciano, A.; Magn. Reson. Chem. 1994, 32, 774.

12. Gibbons, S.; Nat. Prod. Rep. 2004, 21, 263. 


\section{Clara M. A. Tanaka ${ }^{\dagger}$, Vanessa S. C. O. Radke e Cleuza C. da Silva}

Departamento de Química, Universidade Estadual de Maringá, Av. Colombo, 5790, 87020-900 Maringá - PR, Brasil Celso V. Nakamura

Departamento de Análises Clínicas, Universidade Estadual de Maringá, Av. Colombo, 5790, 87020-900 Maringá - PR, Brasil Pollyanna L. de Oliveira, Lucilia Kato e Cecília M. A. de Oliveira*

Instituto de Química, Universidade Federal de Goiás, Campus II, 74000-970 Goiânia - GO, Brasil

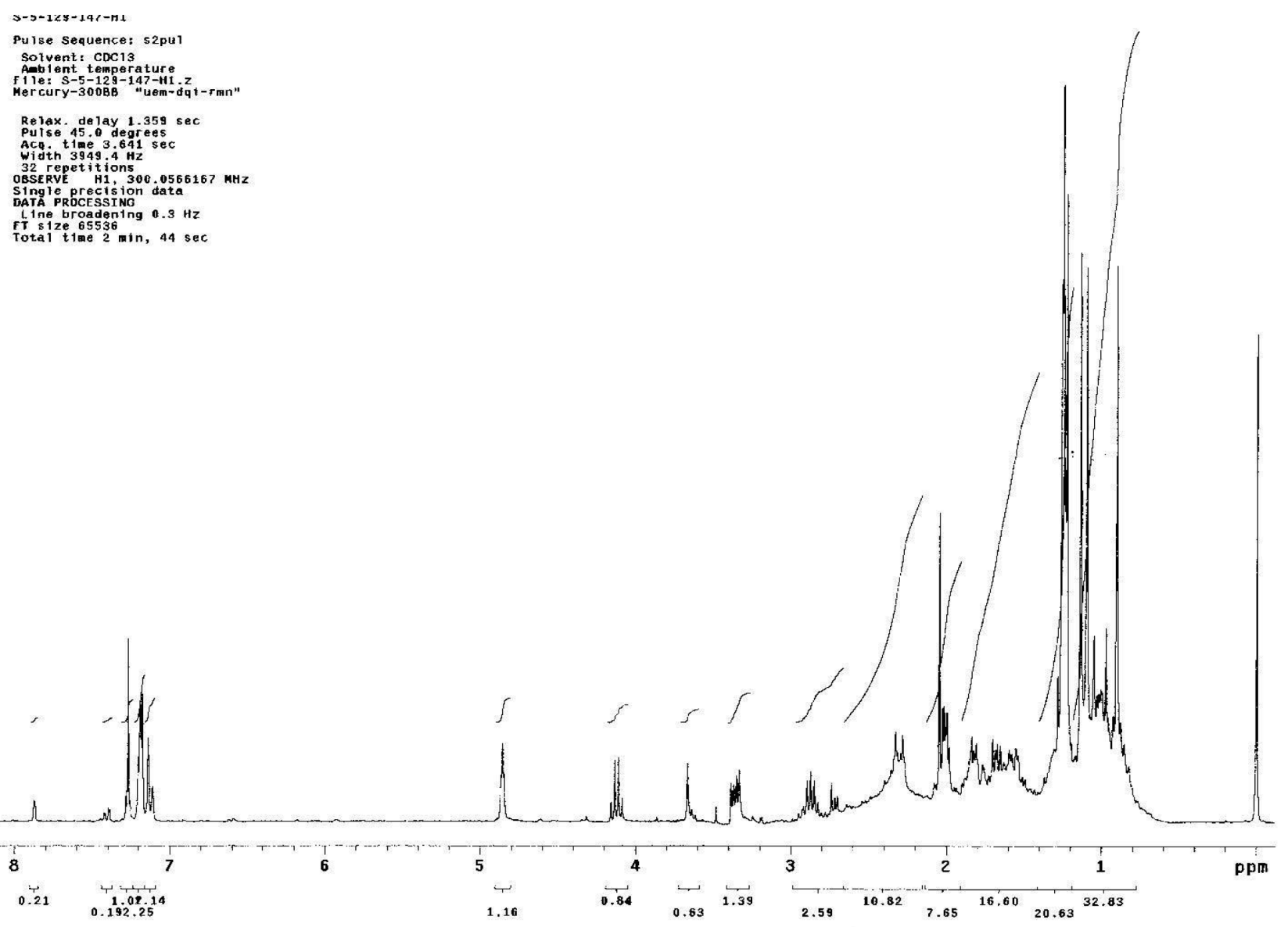

Figure 1S. ${ }^{1} \mathrm{H}$ NMR Spectrum of the compound 1 at $300 \mathrm{MHz}$ in $\mathrm{CDCl} / \mathrm{TMS}$

† This paper is dedicated to our colleague and friend Clara M. A. Tanaka in memoriam

*e-mail: cecilia@quimica.ufg.br 
Pulse Sequence: s2pul

Solvent: $\operatorname{CDC} 13$

Ambient temperature

mercury-300BB "uem-dq $1-$ rmn"

Relax. de lay 1.132 sec

Pulse 45.0 thagrees

Acg. time 0.868 sec

$204818867.9 \mathrm{~Hz}$

OBSERYE C13; $75.4992804 \mathrm{MHZ}$

Low power 1023 de atten.

cont inuous iy on

Single precision data

DATA PROCESSING

line bce

rotal time $1 \mathrm{hr}, 13 \mathrm{~min}, 55 \mathrm{sec}$

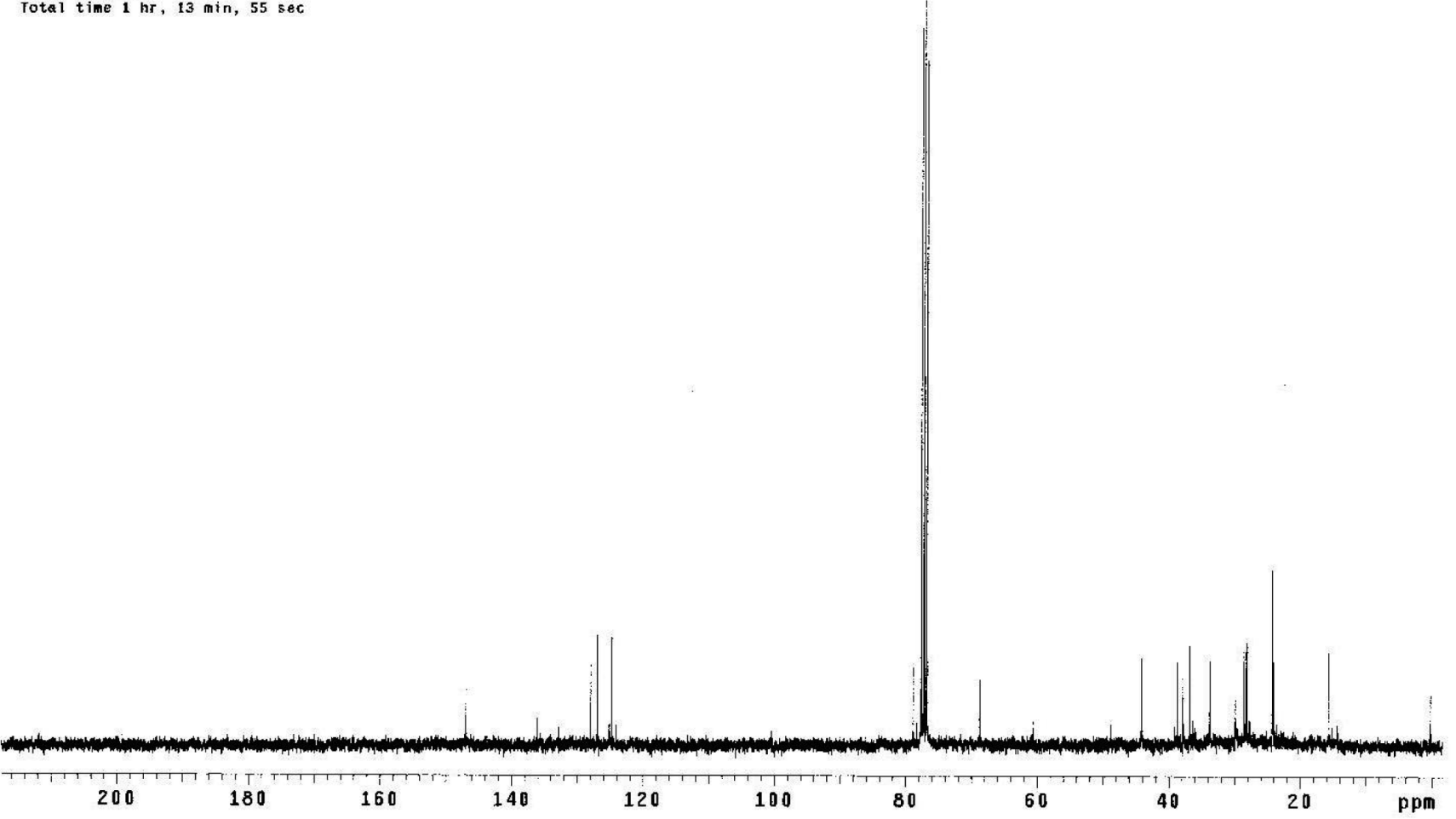

Figure $2 \mathrm{~S} .{ }^{13} \mathrm{C}$ NMR Spectrum of the compound 1 at $75 \mathrm{MHz}$ in $\mathrm{CDCl}$.TMS 
S-5-129-147-cos $Y$

Pulse Sequence: cosy

Solvent: $\operatorname{CDC}_{13}$

Temp. $28.0 \mathrm{C}$. $301.1 \mathrm{~K}$

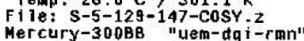

Relax de ray $1.000 \mathrm{sec}$

Acq. time $0.173 \mathrm{sec}$

20 width 2961.2 Hz

12 repetitions

OBSERE H1, 300.0566169 MHZ

single precision data

DATA PROCESSING
Sq. SInE bell $0.086 \mathrm{sec}$

Fq DATA PROCESSING
Sq. 5 ine be $110.043 \mathrm{sec}$

Sq
FT se $2048 \times 2048 \mathrm{sec}$

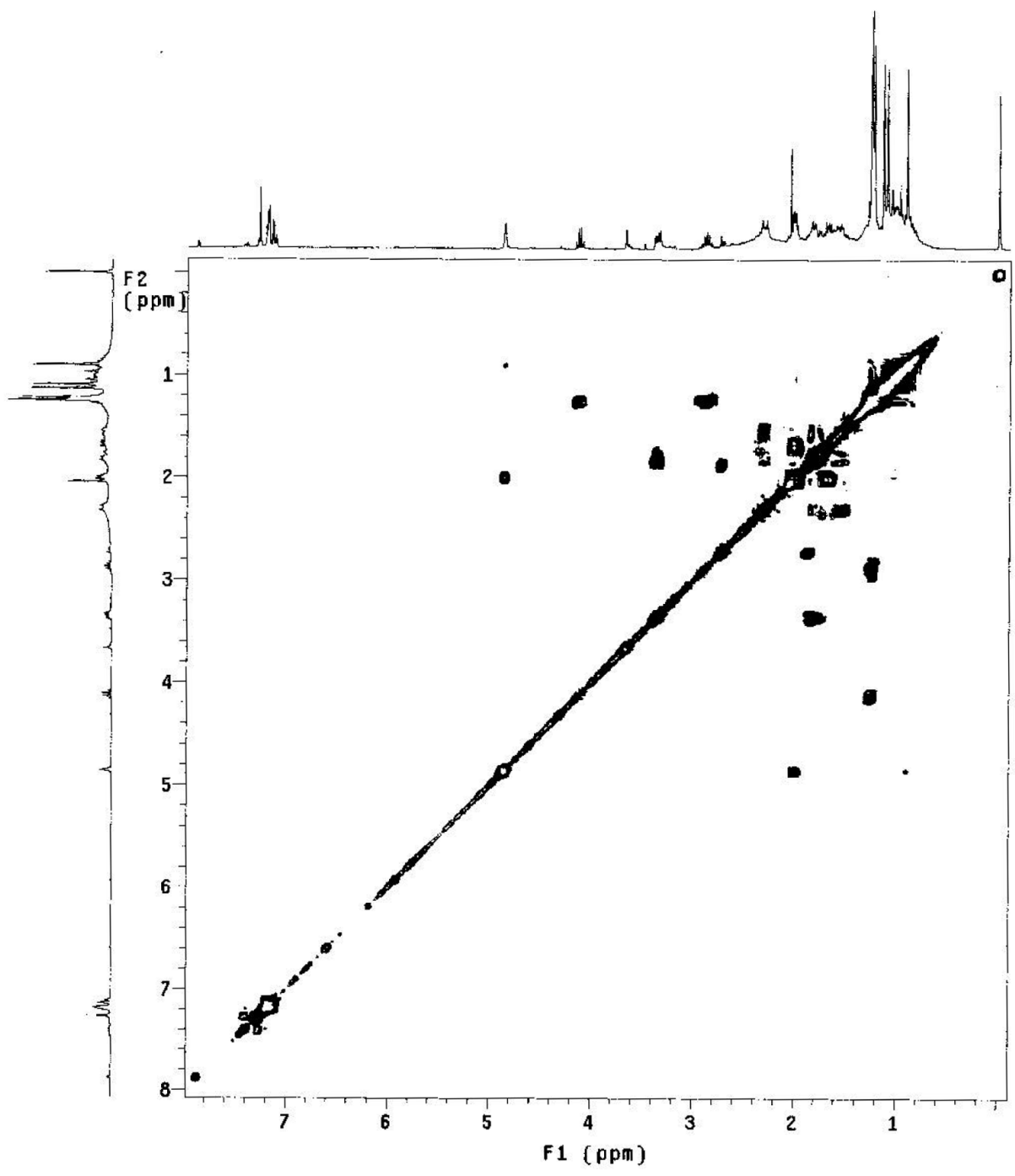

Figure 3S. HMQC Spectrum of the compound 1 at $300 \mathrm{MHz}$ in CDCl/TMS 


\section{S-5-129-1A7-HMQC}

Pulse Sequence: HMQC

Solvent: $\mathrm{CDCl}$

Mercury-300Bb "uem-dq $i-r m e n "$

Re lax. de tay 1.000 sec

Ach time $0.173 \mathrm{sec}$

$2 \mathrm{D}$ width $12820.5 \mathrm{~Hz}$

24 repetitions

$2 \times 128$ increments

OBSERVE H1, $300.0566169 \mathrm{MH}$

ow power 1023 ab atten.

off during delay

single precisis 1on data

Gauss apodization $0.080 \mathrm{sec}$

F1 DATA PROCESSING

tion $0.018 \mathrm{sec}$

FT $512 \mathrm{e} 2048 \times 2048$
Total tine $2 \mathrm{hr}, 55 \mathrm{~min}, 4 \mathrm{sec}$

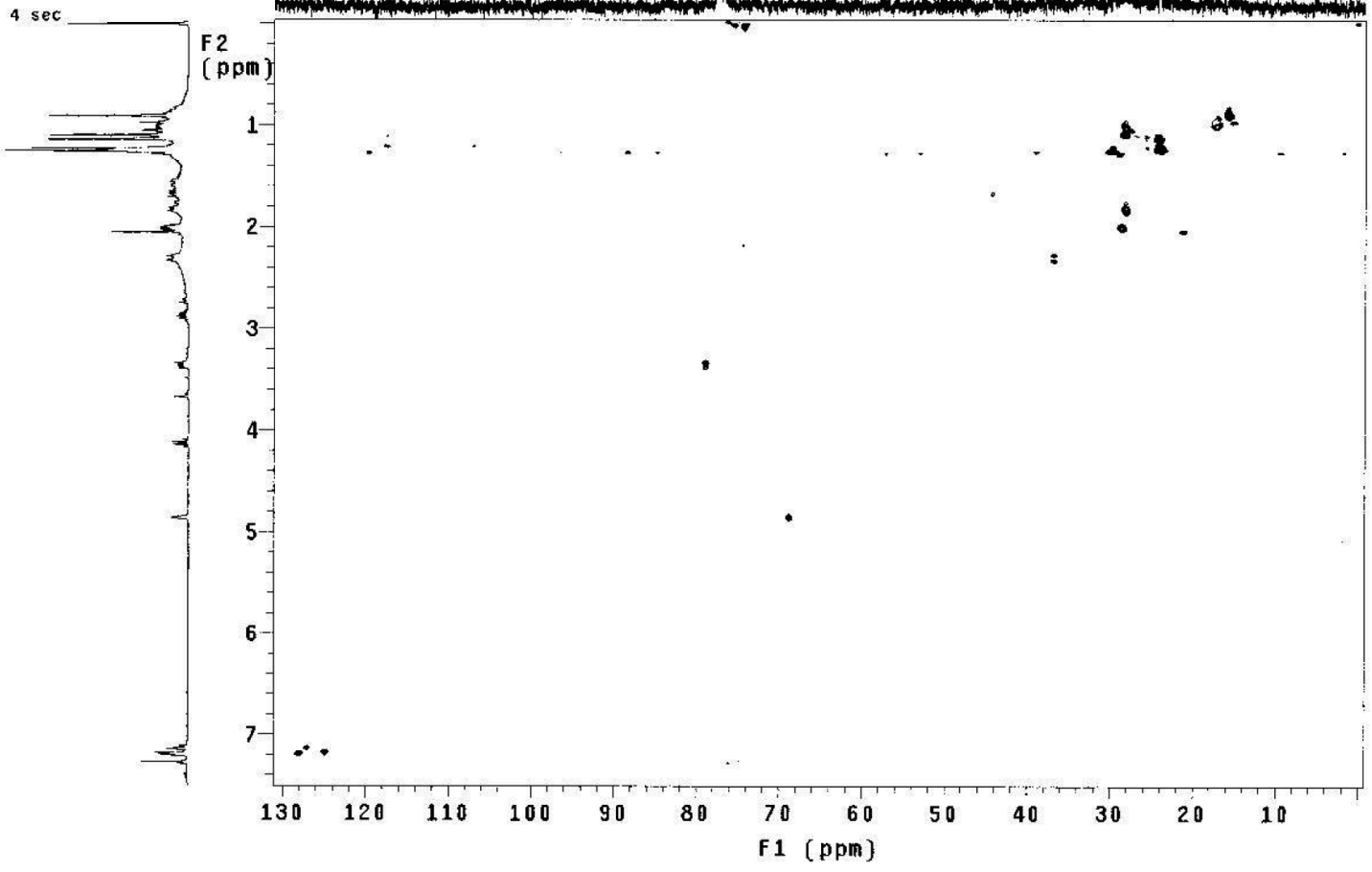

Figure 4S. COSY Spectrum of the compound 1 at $300 \mathrm{MHz}$ in $\mathrm{CDCl} / \mathrm{TMS}$ 